\title{
Quantitative investigation of the annual pattern of follicular development in the nine-banded armadillo (Dasypus novemcinctus)
}

\author{
R. D. Peppler* and J. Canale \\ *Department of Anatomy and Obstetrics and Gynecology, East Tennessee State University \\ College of Medicine, Johnson City, Tennessee 37601 and \\ Louisiana State University Medical Center, New Orleans, Louisiana 70112, U.S.A.
}

\begin{abstract}
Summary. Mature, non-pregnant, female armadillos (Dasypus novemcinctus) were killed throughout the year ( $3-6 /$ month, $N=54$ ) and both ovaries were examined for follicular development. All normal and atretic follicles $>358 \mu$ m were counted. Total number of normal follicles remained constant from January to June but decreased by $50 \%$ in the remaining months except in October and November. Follicles $>978 \mu \mathrm{m}$ (those likely to be ovulated) were found during each month but more ( $>3$ /ovary) were present during April, May, June and October. Atretic follicles remained constant (4-6) except in July and August when the number (10-12) was doubled. A single CL was present in $2 / 4,6 / 6,1 / 6,1 / 3$ and $2 / 3$ animals in July, August, October, November and December, respectively. These data confirm that armadillos ovulate in July and suggest that ovulation may also occur in some animals in late October or November.
\end{abstract}

\section{Introduction}

In 1971, Kirchheimer \& Storrs reported that lepra bacilli replicate in the nine-banded armadillo (Dasypus novemcinctus) producing a disease that resembles lepromatous leprosy. More recently, reports that wild armadillos have a leprosy-like disease has reduced the acceptability of this animal for leprosy research (Binford, Meyers, Walsh, Storrs \& Brown, 1977; Walsh, Storrs, Meyers \& Binford, 1977; Smith et al., 1978). Nonetheless, because the female armadillo delivers monozygous quadruplets, its potential is significant for use in genetic, transplantation and teratology studies. However, the development of the armadillo as a laboratory animal for such studies has been slow because of the lack of information about its reproductive cycle and failure to breed this species in captivity (Anderson \& Benirschke, 1966).

Most of the knowledge about the female armadillo has originated from the investigations of Newman (1912), Hamlett (1932, 1935), Talmage \& Buchanan (1954) and Enders (1966). The present study of follicular development throughout the year is an extension of our earlier work (Peppler \& Stone, 1976; Peppler, 1979) on the reproductive characteristics of female and male armadillos in order to facilitate their breeding in captivity.

\section{Materials and Methods}

Female armadillos (Dasypus novemcinctus) were captured during the year from the wild population in south-east Louisiana. The 54 animals were mature, weighing $4 \cdot 0-5 \cdot 5 \mathrm{~kg}$, and non-pregnant. They were maintained for short periods in groups of 2,3 or 4 in pens $(1.2 \times 1.2$ 
$\mathrm{m})$ under conditions of controlled lighting (fluorescent illumination 07:00-16:00 h) and temperature $\left(25 \pm 1^{\circ} \mathrm{C}\right)$. During the middle of each month 3-6 armadillos were killed and both ovaries removed for quantitative histological evaluation. Ovaries were inspected visually for a corpus luteum (CL) and the presence or absence of a CL was later confirmed microscopically. The ovaries were fixed in Bouin's solution, embedded in paraffin wax, sectioned serially at $5 \mu \mathrm{m}$ and stained with haematoxylin and eosin. Each section was examined with the identity of individual ovaries remaining unknown until all were studied. Follicular size was calculated by measuring the two diameters at right angles to each other in the section containing the oocyte nucleolus. Normal and atretic follicles $>358 \mu \mathrm{m}$ were counted. Atresia was determined by pyknosis of the granulosa nuclei, disintegration of cells bordering the antrum, degeneration of the ovum and distortion of the entire follicle (Ingram, 1962). The lower limit of follicular size $(358 \mu \mathrm{m})$ was selected because the antrum begins to appear in follicles of this size (Newman, 1912). The 8 groups according to which the follicles were classified (358-512 $\mu \mathrm{m} ; 513-667 \mu \mathrm{m}$; 668-822 $\mu \mathrm{m} ; 823-977 \mu \mathrm{m} ; 978-1132 \mu \mathrm{m} ; 1133-1287 \mu \mathrm{m} ; 1288-1442 \mu \mathrm{m} ;>1443 \mu \mathrm{m}$ ) were selected arbitrarily. Both ovaries from each animal were examined and the resulting value (total follicles per animal) was halved to obtain a value per ovary. Six additional animals killed in the months of February $(\mathrm{N}=2)$, March $(\mathrm{N}=2)$, April $(\mathrm{N}=1)$ and December $(\mathrm{N}=1)$ were found to be pregnant. Ovaries from these animals were similarly evaluated for follicular development and the results were compared with those for the non-pregnant animals in these months.

Statistical significance was determined by Student's $t$ test for the changes in number of follicles found during each month. A $P$ value of $<0.05$ was considered significant.

\section{Results}

As shown in Table 1 , the total number of follicles $>358 \mu \mathrm{m}$ remained constant from January until June, but was $50 \%$ less during the remaining months except in October and November.

Table 1. Annual pattern of follicular development in the nine-banded armadillo

\begin{tabular}{|c|c|c|c|c|c|c|c|c|c|c|c|c|}
\hline \multirow{2}{*}{$\begin{array}{l}\text { Follicular } \\
\text { diam. } \\
(\mu \mathrm{m})\end{array}$} & \multicolumn{12}{|c|}{ Mean \pm s.e.m. number of normal follicles in one ovary } \\
\hline & Jan & Feb & Mar & Apr & May & Jun & Jul & Aug & Sep & Oct & Nov & Dec \\
\hline $358-5$ & $\begin{array}{r}3.8 \pm \\
0.4(6)\end{array}$ & $\begin{array}{r}5 \cdot 0 \pm \\
0 \cdot 8(3)\end{array}$ & $\begin{array}{c}6 \cdot 4 \pm \\
1 \cdot 1(4)\end{array}$ & $\begin{array}{r}5.5 \pm \\
0.9(4)\end{array}$ & $\begin{array}{r}4 \cdot 0 \pm \\
1.0(3)\end{array}$ & $\begin{array}{c}5.0 \pm \\
1.2(3)\end{array}$ & $\begin{array}{l}1 \cdot 1 \pm \\
0 \cdot 3(4)\end{array}$ & $\begin{array}{l}1.6 \pm \\
0.5(5)\end{array}$ & $\begin{array}{l}2.8 \pm \\
0.3(3)\end{array}$ & $\begin{array}{r}6 \cdot 5 \pm \\
1 \cdot 7(6)\end{array}$ & $\begin{array}{r}8 \cdot 8 \pm \\
3 \cdot 6(3)\end{array}$ & $\begin{array}{l}3 \cdot 3 \pm \\
0.4(3)\end{array}$ \\
\hline $513-667$ & $\begin{array}{c}3 \cdot 7 \pm \\
1.5(6)\end{array}$ & $\begin{array}{l}4 \cdot 5 \pm \\
1 \cdot 1(3)\end{array}$ & $\begin{array}{c}4 \cdot 3 \pm \\
1.8(4)\end{array}$ & $\begin{array}{c}5.1 \pm \\
0.4(4)\end{array}$ & $\begin{array}{c}3.6 \pm \\
0.9(3)\end{array}$ & $\begin{array}{c}2.6 \pm \\
0.7(3)\end{array}$ & $\begin{array}{l}1.5 \pm \\
0.6(3)\end{array}$ & $\begin{array}{l}1.2 \pm \frac{t}{4} \\
0.4(6)\end{array}$ & $\begin{array}{l}1.5 \pm \\
0.5\left(\frac{5}{3}\right)\end{array}$ & $\begin{array}{r}6 \cdot 3 \pm \\
0 \cdot 8(6)\end{array}$ & $\begin{array}{c}7.7 \pm \\
2 \cdot 8(3)\end{array}$ & $\begin{array}{l}1.8 \pm \\
0.2(3)\end{array}$ \\
\hline $668-822$ & $\begin{array}{c}2.7 \pm \\
0.6(6)\end{array}$ & $\begin{array}{c}2.7 \pm \\
0.6(3)\end{array}$ & $\begin{array}{c}2.8 \pm \\
0.3(3)\end{array}$ & $\begin{array}{c}2.4 \pm \\
0.4(4)\end{array}$ & $\begin{array}{c}3.2 \pm \\
0.6(3)\end{array}$ & $\begin{array}{c}2.0 \pm \\
0.6(3)\end{array}$ & $\begin{array}{l}1.9 \pm \\
0.2(4)\end{array}$ & $\begin{array}{l}2 \cdot 1 \pm \\
1 \cdot 3(4)\end{array}$ & $\begin{array}{l}1.7 \pm \\
0.2(3)\end{array}$ & $\begin{array}{c}4 \cdot 3 \pm \\
0.5(6)\end{array}$ & $\begin{array}{c}4.0 \pm \\
0.9(3)\end{array}$ & $1 \cdot 0(2)$ \\
\hline $823-977$ & $\begin{array}{c}2 \cdot 0 \pm \\
0 \cdot 3(6)\end{array}$ & $1 \cdot 5(2)$ & $\begin{array}{c}3 \cdot 0 \pm \\
1 \cdot 2(3)\end{array}$ & $\begin{array}{c}2.9 \pm \\
0.2(4)\end{array}$ & $\begin{array}{l}1.0 \pm \\
0.2(3)\end{array}$ & $\begin{array}{c}2.0 \pm \\
0.3(3)\end{array}$ & $1 \cdot 5(2)$ & $2 \cdot 8(2)$ & $1.0(2)$ & $\begin{array}{c}2 \cdot 2 \pm \\
0.4(6)\end{array}$ & $1 \cdot 8(2)$ & $1 \cdot 5(2)$ \\
\hline 132 & $\begin{array}{c}1.2 \pm \\
0.2(3)\end{array}$ & $0.5(2)$ & $\begin{array}{c}1.1 \pm \\
0.2(4)\end{array}$ & $\begin{array}{r}1.7 \pm \\
0.4(4)\end{array}$ & $\begin{array}{c}2.0 \pm \\
0.1(3)\end{array}$ & $1 \cdot 5(2)$ & $\begin{array}{l}1.0 \pm \\
0.3(3)\end{array}$ & $\begin{array}{c}0.5 \pm \\
0(3)\end{array}$ & $0 \cdot 5(2)$ & $\begin{array}{c}1.8 \pm \\
0.6(6)\end{array}$ & 2) & 0 \\
\hline $1133-1287$ & 0 & 0 & $1 \cdot 0(2)$ & $\begin{array}{c}0.8 \pm \\
0.3(4)\end{array}$ & $\begin{array}{c}0.8 \pm \\
0.2(3)\end{array}$ & $\begin{array}{l}1.0 \pm \\
0.3(3)\end{array}$ & $1 \cdot 5(1)$ & $\begin{array}{l}0.7 \pm \\
0.2(3)\end{array}$ & 0 & $\begin{array}{c}1.5 \pm \\
0.4(5)\end{array}$ & $0.5(1)$ & 0 \\
\hline $1288-1$ & 0 & 0 & 0 & $1.0(2)$ & $1.0(2)$ & $\begin{array}{c}0.7 \pm \\
0.2(3)\end{array}$ & 0 & $0.8(2)$ & 0 & $\begin{array}{c}0.8 \pm \\
0.2(3)\end{array}$ & 0 & 0 \\
\hline$>144$ & 0 & 0 & 0 & 0 & $1.0(2)$ & 0 & $1.0(1)$ & $0.5(1)$ & 0 & $\begin{array}{c}0.6 \pm \\
0.1(4)\end{array}$ & 0 & 0 \\
\hline $\begin{array}{l}\text { Total number } \\
\text { of follicles } \\
>358 \mu \mathrm{m}\end{array}$ & $\begin{array}{l}12.8 \pm \\
1.9(6)\end{array}$ & $\begin{array}{l}13 \cdot 5 \pm \\
1.4(3)\end{array}$ & $\begin{array}{l}16 \cdot 6 \pm \\
1 \cdot 7(4)\end{array}$ & $\begin{array}{l}18.9 \pm \\
1.9(4)\end{array}$ & $\begin{array}{l}15.9 \pm \\
1.3(3)\end{array}$ & $\begin{array}{l}14 \cdot 3 \pm \\
1.9(3)\end{array}$ & $\begin{array}{c}6 \cdot 2 \pm \\
1 \cdot 3(4)^{*}\end{array}$ & $\begin{array}{l}5.8 \pm \\
1.8(6)\end{array}$ & $\begin{array}{l}7.0 \pm \\
1.5(3)\end{array}$ & $\begin{array}{l}23 \cdot 2 \pm \\
1.9(6)^{*}\end{array}$ & $\begin{array}{l}22 \cdot 0 \pm \\
3 \cdot 5(3)\end{array}$ & $\begin{array}{c}6.8 \pm \\
0.9(3)^{*}\end{array}$ \\
\hline
\end{tabular}

Numbers in parentheses signify numbers of animals in the group with follicles of the respective size ranges.

* $P<0.05$ when compared with value for previous month. 
Analysis of the number of larger-sized follicles $>978 \mu \mathrm{m}$ (those most likely to be ovulated) indicated that there were more follicles $(2 \cdot 7-4 \cdot 1$ follicles/ovary) of this size in the months of April, May, June and October than during any of the other months when values varied from 0 (December) to $1.6(\mathrm{March})$. Furthermore, the percentage of ovaries which contained follicles in each of the four different size groups $>978 \mu \mathrm{m}$ followed a similar pattern. That is, $63 \%$ of the ovaries from animals killed in April had one or more follicles in each of these four groups; $83 \%$, in May; $67 \%$, in June and $74 \%$, in October. The percentage of ovaries from animals killed in other months that had follicles $>978 \mu \mathrm{m}$ varied from $0 \%$ (December) to $45 \%$ (August).

Atretic follicles remained constant (4-6) except in July and August when the number (10-12) was doubled (Text-fig. 1). Similarly, the percentage of atretic follicles per total number of follicles (both normal and atretic) $>358 \mu \mathrm{m}$ remained constant (approximately 20\%) throughout the year except in the months of July and August when there was a greater proportion (65\%) of atretic follicles.

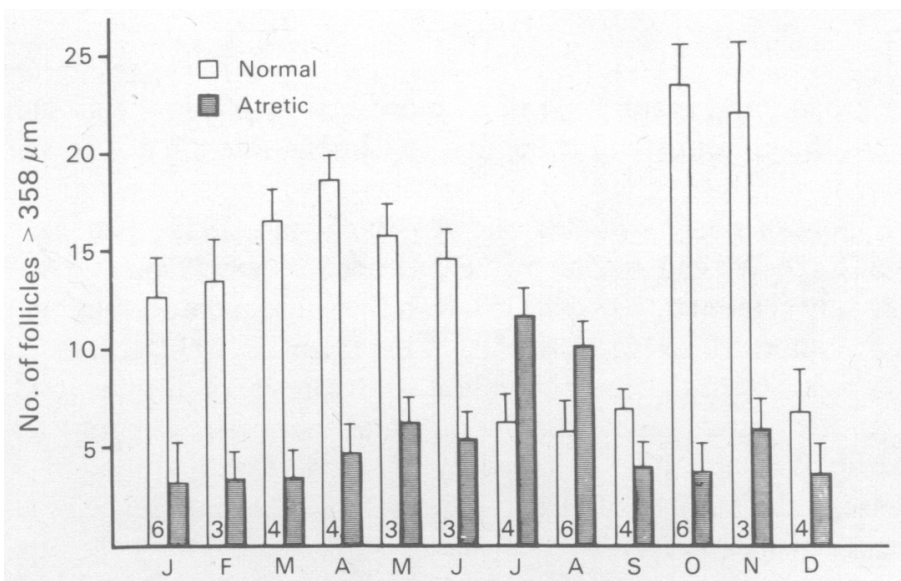

Text-fig. 1. Mean \pm s.e.m. total numbers per ovary of normal and atretic follicles $>358 \mu \mathrm{m}$ in nine-banded armadillos during each month of the year. The number of animals in the group for each month is indicated.

Table 2. Comparison of follicular development in pregnant and non-pregnant armadillos during February and March

\begin{tabular}{ccc}
\hline & \multicolumn{2}{c}{ Mean \pm s.e.m. no. of follicles in one ovary } \\
\cline { 2 - 3 } follicular & \multicolumn{1}{c}{ Pregnant } & Non-pregnant \\
\cline { 2 - 3 } & $4.0 \pm 1.0(4)$ & $5.7 \pm 0.9(7)$ \\
$358-512$ & $5 \cdot 3 \pm 0.9(4)$ & $4.4 \pm 1.4(7)$ \\
$513-667$ & $2.9 \pm 1.0(4)$ & $2.8 \pm 0.5(6)$ \\
$668-822$ & $6.9 \pm 1.4(3)$ & $2.1 \pm 0.9(5)$ \\
$823-977$ & $3.7 \pm 0.8(3)$ & $0.9 \pm 0.2(6)$ \\
$978-1132$ & $3.0(2)$ & $1.0(2)$ \\
$1133-1287$ & $1.3(2)$ & 0 \\
$1288-1442$ & $2.8(2)$ & 0 \\
$>1443$ & $23.7 \pm 2.8(4)$ & $15.3 \pm 1.6(7)$ \\
Total no. of follicles & & \\
$>358 \mu \mathrm{m}$ & &
\end{tabular}

Numbers in parentheses signify numbers of animals in the group with follicles of the respective size ranges.

* $P<0.05$ when compared with value in non-pregnant animals. 
A corpus luteum (CL) was not found in any of the ovaries examined from January to June but a single CL was present in 2/4 animals in July and all 6 in August. None of the ovaries examined in September had a CL but in October, November and December, a CL was present in $1 / 6,1 / 3$ and $2 / 3$ animals respectively.

Since the pattern of follicular development in the ovaries of the pregnant animals killed in both February and March was similar, these animals were combined to form a group of sufficient size that could be compared with non-pregnant animals killed during the same months. The data are shown in Table 2 . In the 4 pregnant animals, more follicles $>358 \mu \mathrm{m}$ were present than in the ovaries of 7 non-pregnant animals, and this increase was the result of more follicles of $>978 \mu \mathrm{m}$ diameter $(6.2$ compared with 1.1$)$ at this time. The pattern of follicular development in the other 2 pregnant animals killed in December and April (one in each month) was comparable to that for the non-pregnant armadillos killed during these respective months (Table 1).

\section{Discussion}

An account of the growth and maturation of an individual follicle in the armadillo was given by Newman (1912), but the present study is the first to demonstrate the annual pattern of follicular development.

The armadillo spontaneously ovulates one egg (Newman, 1912; Hamlett, 1932; Talmage, Buchanan, Kraintz, Lazo-Wasem \& Zarrow, 1954) once a year (Talmage \& Buchanan, 1954) about the middle of July (Hamlett, 1932, 1935), with the subsequent formation of a single corpus luteum (Newman \& Patterson, 1910; Newman, 1912; Hamlett, 1932). Maturation of all but one follicle in the 2 ovaries ceases before ovulation and atresia of the arrested follicles occurs (Newman, 1912). In the present study, the findings that there were (1) more large-sized follicles in the ovary in April, May and June followed by (2) a decrease in July and August with (3) a concomitant increase in the number of atretic follicles and (4) the presence of a CL confirm that animals of this species ovulate in July.

Measurements of seasonal progesterone concentrations (Peppler, 1979) in peripheral plasma indicated that progesterone increased to $10 \mathrm{ng} / \mathrm{ml}$ in June or July and that the presence of a CL correlated with this increase. Subsequently, progesterone decreased to a baseline value and remained at this level throughout the year (August to May) in $60 \%$ of the animals examined ( $N$ $=49$ ). However, in $40 \%$ of the animals, progesterone increased again during the months of November, December and January, and then returned to a baseline level for the remainder of the year (February to May). In the present study there was the substantial increase in the total number of follicles in October and November and some of the animals examined in October, November and December had a CL present in one ovary. Collectively, such data suggest that ovulation may be occurring again in late October or November in some animals. However, there was no corresponding increase in the number of atretic follicles during October, November or December, although in most species, and in the armadillo in July and August, an increase in atresia occurs shortly after ovulation.

If the egg shed in July is fertilized, it enters the uterine cavity and remains in diapause until implantation in mid-October. Gestation lasts $4-4 \frac{1}{2}$ months with parturition occurring in late March or early April. In many species, plasma progesterone decreases before or shortly after parturition. In the armadillo, post-partum progesterone levels return slowly to baseline levels (Peppler, 1979). This finding, in conjunction with the fact that in the present study follicular development was increased during the later part of gestation (February and March), and that atresia was higher during these months $(5.8 \pm 0.9$ atretic follicles/ovary) than in December (3.0) or April (1.5), suggests that post-partum ovulation may be occurring, but further investigation is required. 
This work was supported by grant No. AI 11204 from the National Institutes of Health, U.S.A. We thank Mrs S. Hemelt for technical help and Mrs L. DeLoach for secretarial assistance.

\section{References}

Anderson, J.M. \& Benirschke, K. (1966) The armadillo, Dasypus novemcinctus, in experimental biology. $L a b$. Anim. Care 16, 202-216.

Binford, C.H., Meyers, W.M., Walsh, G.P., Storrs, E.E. \& Brown, H.L. (1977) Naturally acquired leprosylike disease in the nine-banded armadillo (Dasypus novemcinctus): histopathologic and microbiologic studies of tissues. J. Reticuloendothel. Soc. 22, 377-387.

Enders, A.C. (1966) The reproductive cycle of the nine-banded armadillo (Dasypus novemcinctus). Symp. zool. Soc. Lond. 15, 295-310.

Hamlett, G.W.D. (1932) The reproductive cycle in the armadillo. Z. wiss. Zool. 141, 143-157.

Hamlett, G.W.D. (1935) Delayed implantation and discontinuous development in the mammals. $Q$. Rev. Biol. 10, 432-447.

Ingram, D. (1962) Atresia. In The Ovary, 1st edn, pp. 247-273. Ed S. Zuckerman. Academic Press, New York.

Kirchheimer, W.F. \& Storrs, E.E. (1971) Attempts to establish the armadillo (Dasypus novemcinctus Linn.) as a model for the study of leprosy. I. Report of lepromatoid leprosy in an experimentally infected armadillo. Int. J. Lepr. 39, 692-702.

Newman, H.H. (1912) The ovum of the nine-banded armadillo: growth of the ovocytes, maturation and fertilization. Biol. Bull. Mar. Biol. Lab. Woods Hole 23, 100-140.
Newman, H.H. \& Patterson, J.T. (1910) The development of the nine-banded armadillo from primitive streak to birth, with special reference to the question of specific polyembryony. J. Morph. 21, 359-423.

Peppler, R.D. (1979) Reproductive parameters in the nine-banded armadillo. Anat. Rec. 193, 649-650.

Peppler, R.D. \& Stone, S.C. (1976) Plasma progesterone level in the female armadillo during delayed implantation and gestation: preliminary report. $L a b$. Anim. Sci. 26, 501-504.

Smith, J.H., File, S.K., Nagy, B.A., Folse, D.S., Buckner, J.A., Webb, LJ. \& Beverding, A.M. (1978) Leprosylike disease of wild armadillos in French Acadiana, Louisiana. J. Reticuloendothel. Soc. 24, 705-719.

Talmage, R.V. \& Buchanan, G.D. (1954) The armadillo. A review of its natural history, ecology, anatomy and reproductive physiology. The Rice Institute Pamphlet 41, 1-135.

Talmage, R.V., Buchanan, G.D., Kraintz, F.W., LazoWasem, E.A. \& Zarrow, M.X. (1954) The presence of a functional corpus luteum during delayed implantation in the armadillo. J. Endocr. 11, 44-49.

Walsh, G.P., Storrs, E.E., Meyers, W. \& Binford, C.H. (1977) Naturally acquired leprosy-like disease in the nine-banded armadillo (Dasypus novemcinctus): $\mathrm{Re}-$ cent epizootiologic findings. J. Reticuloendothel. Soc. 22, 363-367. 